\title{
Succession planning in small libraries
}

Associate Professor Kerry Smith

Department of Information Studies

Kerry Smith ANZTLA

conference

2010_Succession

planning 
Concern for the need for "succession planning"

-Preparing for staff turnover, even when that staff member is just you

-Ensuring leadership continuity

-Ensuring the continuity of the information service itself

-What will your library be like in the next, say, 5 - 10 years?

McKenna: review of the 8Rs Research Team Canada -1

- Covered professionals and para professionals

-Under representation of minorities and Aboriginal staff

-Poor recognition of immigrant librarians

-Positive exposure to libraries and librarians the best predictor of librarianship as a career choice 


\section{McKenna: - Canada -2}

-Average age of new librarian recruits is $\mathbf{3 7}$

-Major barrier to recruit were:

- budget constraints,

-hire freeze,

-difficult to fill competencies (leadership potential, ability to respond flexibly to change, ability to handle high volume workload).

-Librarians are mostly satisfied with their work

-Workload often not manageable

McKenna: - Canada - 3

-Limited opportunity for promotion within the organization

-Some dissatisfaction with MLIS courses

-Requirement for continual PD

-Gap between desire to be involved with decision making and actual involvement

-Gap between desire to be treated with respect and perception that respect is conveyed

-Two most important factors: respectful treatment and job that allows you to learn new skills and grow (the latter very tricky in a small library) 
McMahan \& Masias, 2009

-WHAT SORT OF PERSONIS DO YOU NEED TO MANAGE THE LIBRARY?

-through focus groups found that skills required were those that were lacking:

-Vision

-Technology application

-Teamwork

-Self management

McMahan \& Masias, 2009 - 2

-Commitment to professional development

-Problem solving

-Leadership

-Planning and evaluation

-Information management

-Customer service

-Communication

-Attention to detail 
-It is easy for us to think that we have all of these characteristics, but do we?

-And how will we know a new replacement will have them as well?

-We do our best to cover our bases in advertisements, but do these always work?

McMahan \& Masias, 2009 - 3

\section{HOW?}

-Buy it - recruit from outside

-Buy it to grow - hire with the expectation that the new staff member will grow into the position

-Grow it - from internal appointment

-Borrow it - on temporary or rotating basis 
McMahan \& Masias, 2009 - 4

GOALS FOR YOUR SUCCESSION PLAN WILL HELP YOU THINK FORWARD

-provide continuity and retain institutional knowledge

-Ensure employees have the tools they need for today and tomorrow's jobs?

\section{WHERE DO WE START AND ON WHAT} SHOULD WE FOCUS?

McMahan \& Masias, 2009 - 5

\section{THINGS TO REMEMBER}

-Ensure involvement of staff members from all over the organization;

-Read the library and related literature -KISS

-make sure staff realize the benefits of the plan

-get buy-in from management and keep kemsum werna them informed. 


\section{The best laid plans....}

The trick is to find a library professional who, like you?:

-Is a risk taker, innovator, and influencer within the profession and their organizations

-Is a networker

-builds collaborative and relationship building opportunities

-Is a JOAT - Jack/Jill of all trades and master of none?

\section{NETWORKING}

The successful special and one-person librarian is a huge networker. You network amongst:

- professional colleagues,

-work colleagues,

-the industry you are working in,

-your outside interests and

-the profession to which you belong. If you do not show professional responsibility and engagement with colleagues, then you will be ignored.

-attend conferences to keep up to date with technological and other developments in your profession and industry. 


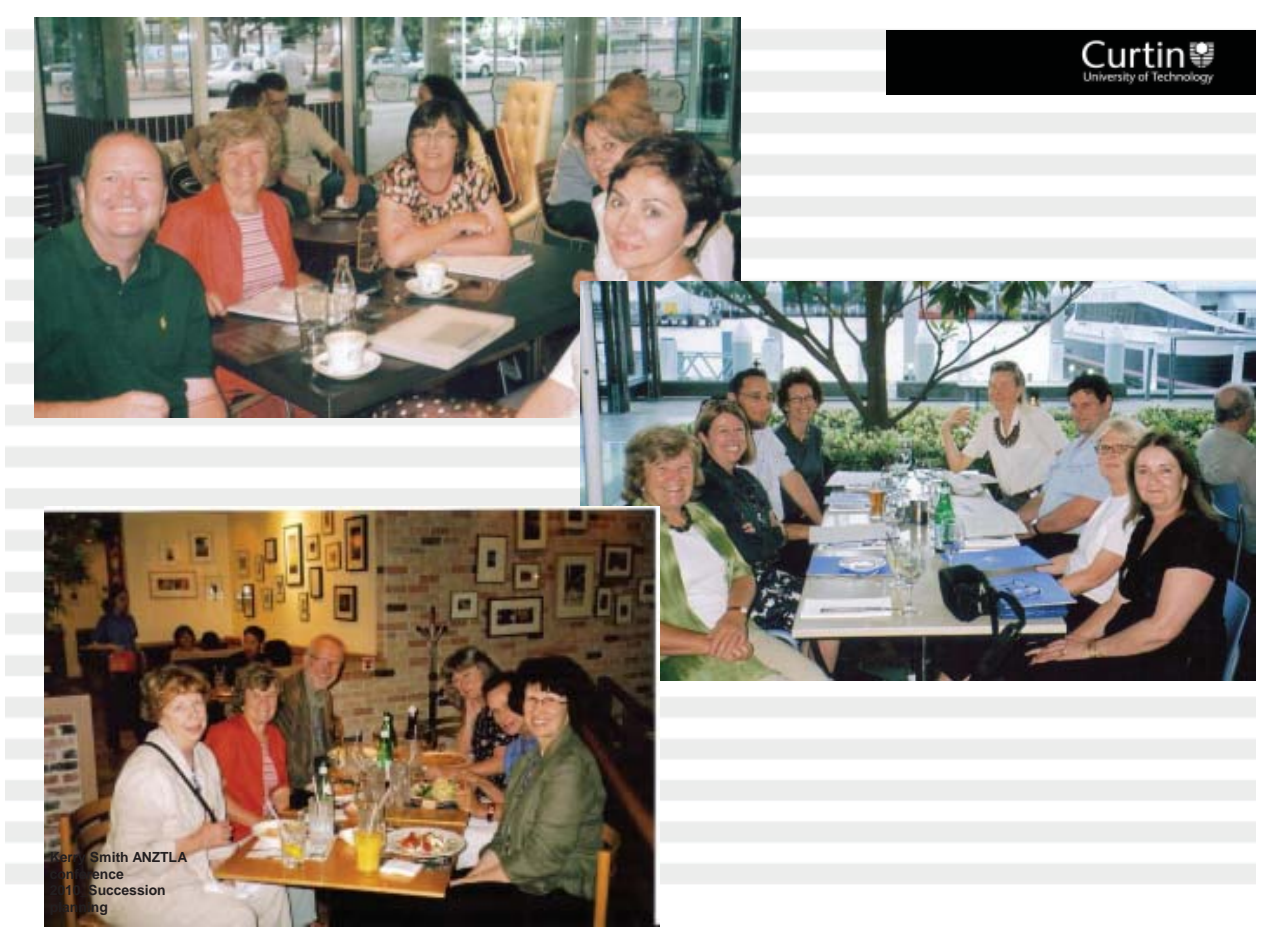

Curting

Abram (2010) believes that

-Special librarians are more about communicating the value of the individual professional and the profession than the actual physical library (although that can be a part of it). It can be all about the personal and the professional relationship of trust and respect with your management, end-users and colleagues and that isn't always measureable while it can still be very powerful! (n.p.). 


\section{The embedded librarian}

-special and one person librarians to become a true part of the organisation they serve.

-they "share a common focus on delivering customized services to clients with well-defined needs" (Shumaker (2010) p. 10).

-Abram (2010b) "success as an embedded librarian requires being open to developing relationships and working side by side with people who use your services" (p. 53).

-St Clair, Harriston \& Pellizzi (2003, Larry Prusak (2009)

- business approach

Relevant characteristics?

-Do these characteristics describe you and the service you offer?

-Are these the characteristics of the new graduate?

-Do library schools in Australia encourage such characteristics? 


\section{Nevertheless:}

-Towards the end of 2009 the Board of the Special Libraries Association (SLA) put forward a referendum to

change the name of the Association from SLA to the Association for Strategic Knowledge Professionals (ASKPro),

with 2071 members voting "yes" and 3225 voting "no" (SLA, 2009). The email list discussions were fast and furious and quite polarized either way. (The Australian translation of ASKPro was not really appreciated by our North American colleagues but it did cause some mirth). ASKPro = ask a prostitute

What do you need to do to enable this?

-find

-mentor

-employ

-groom

-The successor will not always be young

-The future - no physical library, KM ? 


\section{References}

Abram (2010). Value of special libraries. Retrieved April 8, 2010 from http://stephenslighthouse.com/2010/04/07/value-of-special-libraries/

Hallam, G. (2010, March). Queensland government agency libraries review: Literature review. DPC Job reference number: DPC 45-09.

McKenna, J. (2007). Canadian library human resources short-term supply and demand crisis is averted, but a significant long-term crisis must be addressed. Evidence Based Library and Information Practice, 2(1), 121-127.

McMahan \& Masias, 2009). Developing a succession plan for a library. Information Outlook, 13(7), 29-

Prusak, L. (2009, December). You can never have too much knowledge. Information Outlook, 13(8), 11-13.

Shumaker, D. (2010, January/February). A wide range of approaches. Information Outlook, 14(1), 1011.

St. Clair, G., Harriston, V., \& Pellizzi, T.A. (2003, June). Toward world-class knowledge services: Emerging trends in specialized research libraries. Part One: the Management Perspective. Information Outlook, 10-12, 14, 16, 18

Kerry Smith ANZTLA

Kerry Smith ANzTh
conference
2010 Succession

2010_Succes 